\title{
Implementation of Data Mining Grouping Product Order Distribution Center In PT. Indomarco Prismatama Medan Branch
}

\author{
Nico Setiawan ${ }^{1}$, Post Marto Hasugian ${ }^{2}$ \\ ${ }^{1.2}$ Informatics Engineering Study Program, STMIK Pelita Nusantara, Jl. Iskandar Muda No. 1 \\ Medan, North Sumatra, Indonesia 20154. \\ E-mail:setiawannico5@gmail.com
}

\begin{abstract}
Data mining is the technique of extracting previously unknown information in a set of data in the database. Data mining has been applied in various fields which require extracting information. One of them in groupings of data. Grouping is used to divide a set of data into several sections that are useful to more easily identify a class of data. Distribution companies can use groupings of one to determine the intensity of the volume of goods ordered. The study analyzes the application of data mining algorithms $k$ meansclustering to elicit information from the data ordering goods contained in centerPT distribution. Indomarco Prismatama Medan branch. That is by using a number of items and the total amount of the quantity of each item ordered.
\end{abstract}

Keywords: Data mining, k-means algorithm, clustering

\section{Introduction}

Data mining is an activity undertaken to explore the information-shaped pattern or grouping of data in a data set that has a large enough quantities to be taken of information that can be used to help make decisions. Data mining is also interpreted as an interesting pattern extraction of large amounts of data. In which a pattern is said to be interesting if the pattern is not implicit, previously unknown, but useful.

PT. Indomarco Prismatama is one of the largest franchised retail company in Indonesia. PT. Indomarco Prismatama have the space used to store merchandise while before they were distributed to retail stores called Distribution center. Distribution centers deliver goods based on data from the first order of goods sent by the store to the distribution center.

In the process of packing the goods to be delivered to the store frequently arise where frequent delays due to packing a large number of goods demand, but the number of personnel in the area are not qualified to do the packing at the request of such large items.

Based on the above problems, the researchers tried grouping goods order data with data mining. utilize goods order data sent by the store to find out what items are ordered by the store.

\section{Theory}

\subsection{Data Mining}

Data mining is the process to obtain useful information from large data base warehouse. Also defined as the extraction of new information, taken from a large a chunk of data that help in decision-making [1].

Data mining is the method used for extraction of hidden predictive information on the database [2]. The term data mining has several views, such as knowledge discovery or pattern recognition. the two terms actually has their accuracy, respectively. The term knowledge discovery or invention of appropriate knowledge for use purpose of data mining is to obtain knowledge that is still hidden inside a chunk of data. The term pattern recognition or pattern recognition also remains to be used because of the knowledge that was about to be extracted is shaped patterns that still need to be explored from a chunk of data that is facing [1].

\section{$2.2 \quad$ K-Means Clustering}

$\mathrm{K}$-means clustering method is a method of group analysis that led to the object of observation of partitioning $\mathrm{N}$ into $\mathrm{K}$ groups (clusters) where each object observation is owned by a group with the closest mean 
[1]. K-means clustering can be interpreted as one of the data mining tools aimed at grouping the objects into clusters [2]. Grouping the data with K-means clustering algorithm is generally performed in the following order:

a. Define $\mathrm{k}$ as the number of clusters to be formed.

b. Initialize $\mathrm{k}$ centroid (center point cluster) beginning at random.

c. Allocate any data or object to the nearest cluster. The distance between the object and the distance between objects in the cluster. specific data with the specified distance between the center of the cluster. To calculate the distance of all data to each cluster center, can use distances theory ecuilidean defined as the following equation.

$\overline{n_{k=1}^{n}\left(p_{k}-q_{k}\right)^{2}}$

Distance to the center of the cluster is recalculated with the current cluster membership. Center of the cluster is the average of all the data or objects in a particular cluster, if desired can also use the median value of the cluster.

d. Repeat step three until the results of iteration is worth the same as the previous iteration.

\section{Research methods}

Research in an attempt to obtain the truth. research must be based on scientific thinking process as outlined in the scientific method.

Research framework is procedural used in conducting research studies in order to run smoothly and systematically with prior calculation phases or activities to be undertaken while doing this penelitian.Berikut is the framework of this study.

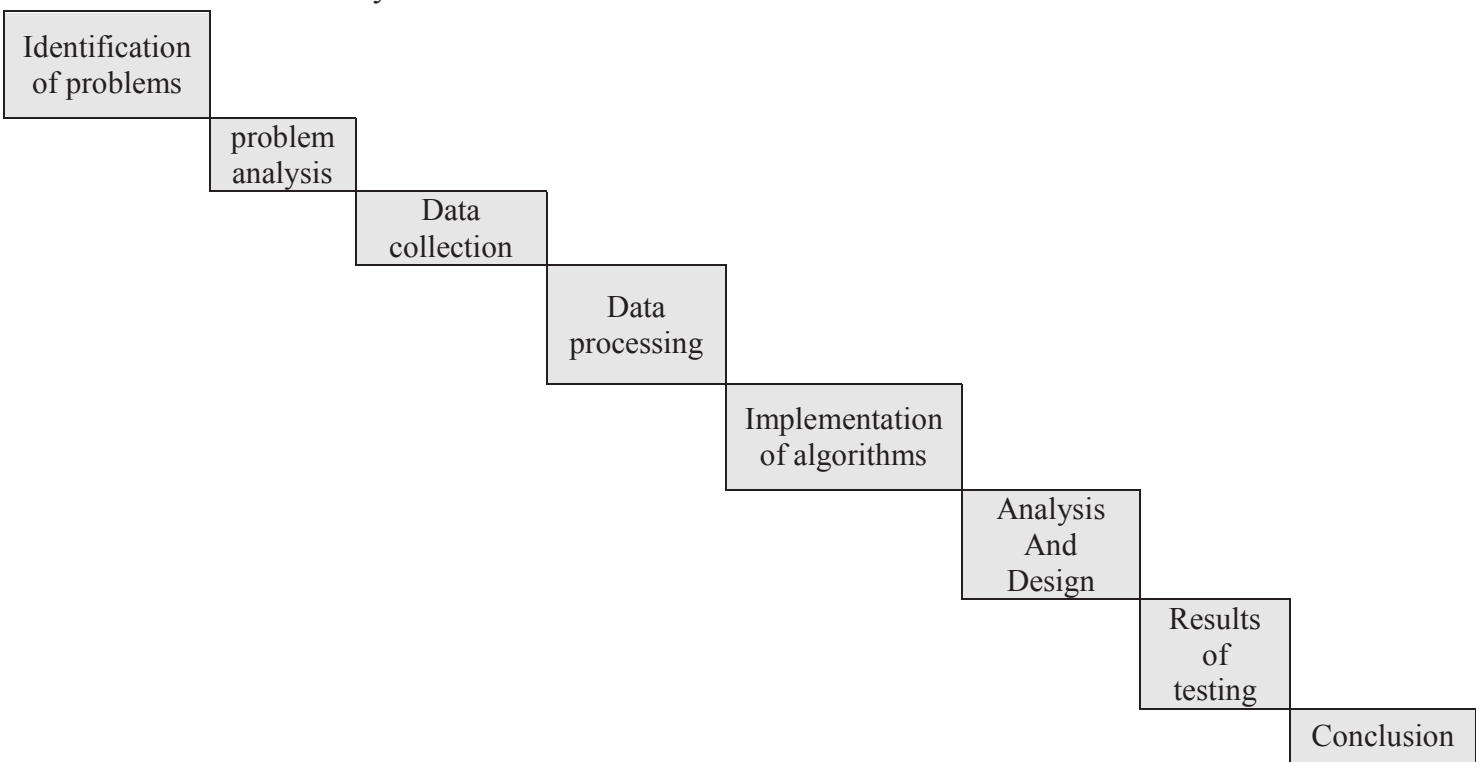

Fig 1. Framework Research

\section{Analysis and Design}

In this study, there are 19 data to be grouped. This data is the reservation data that have been through the cleaning process data in accordance with the stages of data mining.

Table 1.

The data will be in the cluster

\begin{tabular}{cll}
\hline NO & ITEM & \multicolumn{1}{c}{ QTY } \\
\hline 1 & 2,309 & 6.678 \\
2 & 3,869 & 15.328 \\
\hline
\end{tabular}




\begin{tabular}{cll}
\hline NO & \multicolumn{1}{c}{ ITEM } & \multicolumn{1}{c}{ QTY } \\
\hline 3 & 4.838 & 15,450 \\
4 & 4,747 & 20.829 \\
5 & 4,205 & 39.344 \\
6 & 13.081 & 43.006 \\
7 & 16.448 & 50.493 \\
8 & 14.276 & 60.358 \\
9 & 23.366 & 62.080 \\
10 & 11.580 & 66.982 \\
11 & 28.743 & 71.944 \\
12 & 10.664 & 77.262 \\
13 & 3,633 & 92.322 \\
14 & 16.702 & 99.961 \\
15 & 39.476 & 108.625 \\
16 & 7.498 & 113.527 \\
17 & 30.218 & 124.167 \\
18 & 27.583 & 129.662 \\
19 & 34.215 & 148.741 \\
\hline
\end{tabular}

Step 1: determine how many clusters to be formed. In this research will dibetuk 4 cluster.

Step 2: determine the value of the first cluster centers randomly from the data that will be in the cluster

$$
\text { Table } 2 .
$$

Center Clusterawal

\begin{tabular}{ccc}
\hline cluster & item & Qty \\
\hline C1 & 34.215 & 148.741 \\
C2 & 10.664 & 77.262 \\
C3 & 14.276 & 60.358 \\
C4 & 2,309 & 6.678 \\
\hline
\end{tabular}

Step 3: Allocate any data or object to the nearest cluster. The distance between the object and the distance between objects with a particular cluster is determined. the distance between data centers using the theory of distance ecuilidean Cluster. The first calculated distance data by the central cluster 1 first, followed by calculating the distance to the next cluster center.

a.

$$
\begin{aligned}
& 2.309-34.215^{2}+ \\
& 6.678-148.741^{2}=145602 \\
& \begin{array}{c}
3.869-34.215^{2}+ \\
(15.328-148.741)^{2}
\end{array}=136821
\end{aligned}
$$

b.

$4.838-34.215^{2}+$

$(15.450-148.741)^{2}=136490$

d.
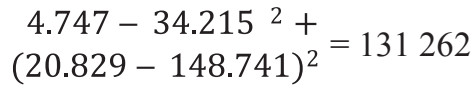

e.

$$
4.205-34.215^{2}+
$$

$$
\frac{4.205-34.215^{2}+}{(39.344-148.741)^{2}}=113439
$$

$$
\text { 19. }=0 \begin{array}{r}
34.215-34.215^{2}+ \\
(148.741-148.741)^{2}
\end{array}
$$

Resulting in the following:

Table 3

The distance of each data to a cluster 1

\begin{tabular}{cccc}
\hline to-data & item & Qty & Distance to C1 \\
\hline 1 & 2,309 & 6.678 & 145.602 \\
2 & 3,869 & 15.328 & 136.821 \\
3 & 4.838 & 15,450 & 136.490 \\
\hline
\end{tabular}




\begin{tabular}{cccc}
\hline to-data & item & Qty & Distance to C1 \\
\hline 4 & 4,747 & 20.829 & 131.262 \\
5 & 4,205 & 39.344 & 113.439 \\
6 & 13.081 & 43.006 & 107.826 \\
7 & 16.448 & 50.493 & 99.842 \\
8 & 14.276 & 60.358 & 90.604 \\
9 & 23.366 & 62.080 & 87.337 \\
10 & 11.580 & 66.982 & 84.834 \\
11 & 28.743 & 71.944 & 76.992 \\
12 & 10.664 & 77.262 & 75.259 \\
13 & 3,633 & 92.322 & 64.174 \\
14 & 16.702 & 99.961 & 51.829 \\
15 & 39.476 & 108.625 & 40.460 \\
16 & 7.498 & 113.527 & 44.202 \\
17 & 30.218 & 124.167 & 24.897 \\
18 & 27.583 & 129.662 & 20.199 \\
19 & 34.215 & 148.741 & - \\
\hline
\end{tabular}

Do the same calculation for the entire center of the cluster that had been predetermined.

Step 4: calculate the shortest distance between the data with each cluster center. The data are part of a cluster center clusterapabila distance with the smallest distance between clusters of data more

Table 3.

Each member of the Cluster

\begin{tabular}{|} 
Cluster members 1 \\
\begin{tabular}{|c|c|c|c|}
\hline to-data & item & Qty & cluster \\
\hline 15 & 39.476 & 108.625 & 1 \\
\hline 17 & 30.218 & 124.167 & 1 \\
\hline 18 & 27.583 & 129.662 & 1 \\
\hline 19 & 34.215 & 148.741 & 1 \\
\hline Total & $\mathbf{1 3 1 . 4 9 2}$ & $\mathbf{5 1 1 . 1 9 5}$ & \\
\hline
\end{tabular}
\end{tabular}

Cluster member 2
\begin{tabular}{|c|c|c|c|}
\hline to-data & item & Qty & cluster \\
\hline 12 & 10.664 & 77.262 & 2 \\
\hline 13 & 3,633 & 92.322 & 2 \\
\hline 14 & 16.702 & 99.961 & 2 \\
\hline 16 & 7.498 & 113.527 & 2 \\
\hline Total & $\mathbf{3 8 . 4 9 7}$ & $\mathbf{3 8 3 . 0 7 2}$ & \\
\hline
\end{tabular}

\begin{tabular}{|} 
Cluster members 3 \\
\hline to-data & item & Qty & cluster \\
\hline 5 & 4,205 & 39.344 & 3 \\
\hline 6 & 13.081 & 43.006 & 3 \\
\hline 7 & 16.448 & 50.493 & 3 \\
\hline 8 & 14.276 & 60.358 & 3 \\
\hline 9 & 23.366 & 62.080 & 3 \\
\hline 10 & 11.580 & 66.982 & 3 \\
\hline 11 & 28.743 & 71.944 & 3 \\
\hline Total & $\mathbf{1 1 1 . 6 9 9}$ & $\mathbf{3 9 4 . 2 0 7}$ & \\
\hline
\end{tabular}

Cluster member 4

\begin{tabular}{|c|c|c|c|}
\hline to-data & item & Qty & cluster \\
\hline 1 & 2,309 & 6.678 & 4 \\
\hline 2 & 3,869 & 15.328 & 4 \\
\hline 3 & 4.838 & 15,450 & 4 \\
\hline 4 & 4,747 & 20.829 & 4 \\
\hline Total & $\mathbf{1 5 . 7 6 3}$ & $\mathbf{5 8 . 2 8 5}$ & \\
\hline
\end{tabular}

Step 5: Calculate new cluster centers based on the new data is generated, by adding data on each column of data and then divided by the data incorporated in each cluster

Table 4.

Determination New Cluster

\begin{tabular}{|c|c|c|c|c|c|}
\hline \multirow{2}{*}{ cluster } & \multicolumn{3}{|c|}{ amount } & \multicolumn{2}{c|}{ New Cluster Center } \\
\cline { 2 - 6 } & item & Qty & Member & item & Qty \\
\hline cluster 1 & 131.492 & 511.195 & 4 & 32.873 & 127.799 \\
\hline cluster 2 & 38.497 & 383.072 & 4 & 9.624 & 95.768 \\
\hline cluster 3 & 111.699 & 394.207 & 7 & 15.957 & 56.315 \\
\hline cluster 4 & 15.763 & 58.285 & 4 & 3.941 & 14.571 \\
\hline
\end{tabular}


Step 6: Repeat step three to back calculate the distance of each data center newly formed cluster

Step 7: compare the results obtained, whether there are data to be migrated. If there are data to move the cluster then proceed to the next iteration calculation. If there is no data to move the cluster then the calculation is completed, and the latest iteration is the result of clustering.

In this study, the calculation stopped at iteration 4 , with the result

Table 5.

The final result Clustering

\begin{tabular}{cccc}
\hline to-data & item & Qty & cluster \\
\hline 1 & 2,309 & 6.678 & 4 \\
2 & 3,869 & 15.328 & 4 \\
3 & 4.838 & 15,450 & 4 \\
4 & 4,747 & 20.829 & 4 \\
5 & 4,205 & 39.344 & 4 \\
6 & 13.081 & 43.006 & 3 \\
7 & 16.448 & 50.493 & 3 \\
8 & 14.276 & 60.358 & 3 \\
9 & 23.366 & 62.080 & 3 \\
10 & 11.580 & 66.982 & 3 \\
11 & 28.743 & 71.944 & 3 \\
12 & 10.664 & 77.262 & 2 \\
13 & 3,633 & 92.322 & 2 \\
14 & 16.702 & 99.961 & 2 \\
15 & 39.476 & 108.625 & 1 \\
16 & 7.498 & 113.527 & 2 \\
17 & 30.218 & 124.167 & 1 \\
18 & 27.583 & 129.662 & 1 \\
19 & 34.215 & 148.741 & 1 \\
\hline
\end{tabular}

The above table is a table of the results of the processing of k-means cluster is indicative of a column in the cluster where the data is located.

\section{System implementation}

Implementation of the system is the process of implementation of the system in a real situation. In the implementation phase of the system are faced with real problems as the system is designed, in this case the system is used to perform the data clustering ordering goods at PT. Indomarco Prismatama Cab. Field. on analysis K-Meansthere is a menu that can be used in order to report the results of the analysis of K-Means can be displayed in the form of iteration-iteration. Here are the results of K-Means analysis report can be seen in Figure 2 .

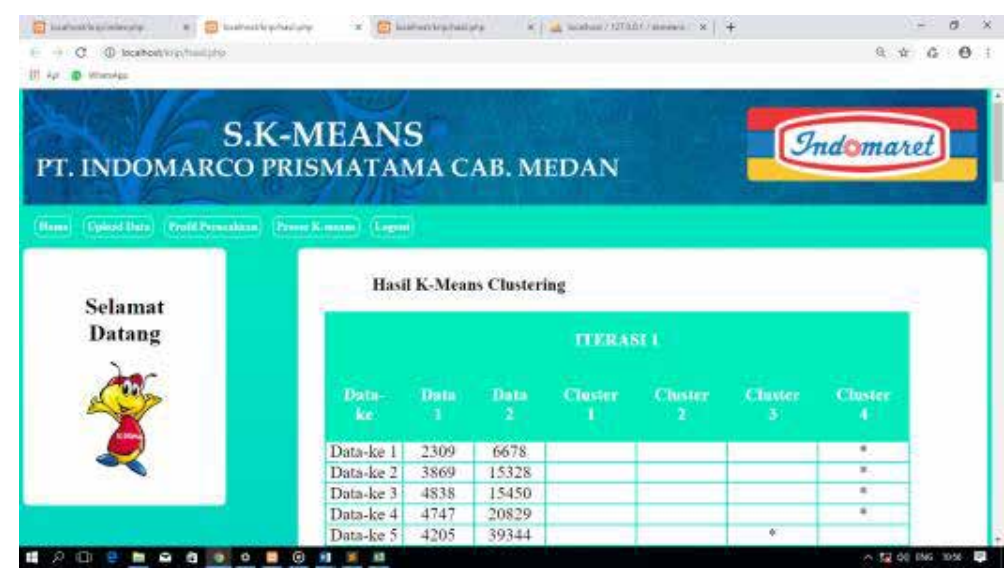

Figure 2. Display Reports Analysis K-Means 


\section{Conclusion}

Based on the results of research and experimentation in the implementation of data mining system to categorize the data ordering goods at the distribution center PT. Indomarco Prismatama Medan branch can be concluded as follows:

a. Presentation of data clustering results are presented in the form of iteration displayed on web pages. And displayed throughout the iterations that are included in the calculation of clustering. This iteration shaped calculation results can be used to perform an analysis of clustered data.

b. Application of k-means clustering method dalampengelompokan goods order data can help analyze the data that existed before ordering goods. Information gained from the implementation of $\mathrm{k}$-means clustering method can be used to help make decisions to address the problems that occurred previously.

c. Application design data grouping based website is very well done for the implementation of the website is easy to use and relatively lightweight application be a distinct advantage.

\section{Reference}

[1] Prasetyo, E. 2017. Data Mining: Konsep dan Aplikasi Menggunakan MATLAB, Yogyakarta: C.V Andi Offset.

[2] Rosa, A.S, Salahuddin, M. 2018. Rekayasa Perangkat Lunak-Terstruktur Dan Berorientasi Objek. Bandung: INFORMATIKA.

[3] Vulandari, R. T. 2018. Data Mining: Teori dan Aplikasi Rapidminer, Yogyakarta: Gava media.

[4] Destiningrum, M. \& Adrian, J. Q. Sistem Informasi Penjadwalan Dokter Berbasis Web dengan Menggunakan Framework codeigniter (Studi Kasus : Rumah Sakit Yukum Medical Center), Jurnal Teknoinfo, 2017, 11(2), 3.

[5] Darmi, Y. \& Setiawan, A. Penerapan Metode Clustering K-means dalam Pengelompokan Penjualan Produk, Jurnal Media Infotama, 2016, 12(2), 149-150.

[6] Aprianto, B. W., Niswatin, R. K., Hariri, F. R.Sistem Pemgelompokan dan Rekomendasi Pengadaan Barang dengan Menggunakan Metode K-Means, Simki-Techsain, 2018, 2(3), 5.

[8] Bastian, A., Sujadi H., Febrianto. G. Penerapan Algoritma K-means Clustering Analisis Pada Penyakit Menular Manusia (Studi Kasus Kabupaten Majalengka), Jurnal Sistem Informasi, 2018, 14(1), 28-29.

[9] Harminingtyas, R. Analisis Layanan Website Sebagai Media Promosi, Media Transaksi dan Media Informasi dan Pengaruhnya Terhadap Brand Image Perusahaan Pada Hotel Ciputra di Kota Semarang, Jurnal STIE Semarang, 2014, 6(3), 42.

[10] Prayitno, A.\& Safitri, Y.Pemanfaatan Sistem Informasi Perpustakaan Digital Berbasis Website Untuk Para Penulis, IJSE-Indonesian Journal on Software Engineering, 2015, 1(1),2.

[11] Raval, U. R., \&Jani. C.Implementing \& Improvisation of K-means Clustering Algorithm, International Journal of Computer Science and Mobile Computing, 2016, 5(5), 193. 